\title{
Nudging and obesity: How to get rid of paternalism?
}

\author{
I gnaas Devisch \\ Artevelde University College, Ghent University, Belgium \\ Correspondence: Ignaas Devisch. Address: Lange Boomgaardstraat 8, 9000 Ghent - Belgium. Telephone: \\ 0032-498-574-801. E-mail: Ignaas.Devisch@Ugent.be
}

Received: November 8, 2011

Accepted: December 28, 2011 Published: May 1, 2012

DOI : $10.5430 /$ jnep.v2n2p89

URL: http://dx.doi.org/10.5430/jnep.v2n2p89

\section{Abstract}

This paper reflects upon the conditions how 'nudging' can change individual health choices without being paternalistic and therefore can be defined as an instrument of social justice? So many problems we are facing in today's nursing are situated at the intersection of autonomy and heteronomy, i.e. why well informed and autonomous people make unhealthy lifestyle choices. If people do not choose what they want, this is not simply caused by their lack of character or capability, but also by the fact that absolute autonomy is impossible; also autonomous individuals are 'contaminated' by heteronymous aspects, by influences from 'outside'. In an earlier article I made an analysis of my neologism 'oughtonomy' to support the thesis that when it comes down to human existence, autonomy and heteronomy are intertwined, more than they are merely opposites.

Although nudging might be of help in many nursing settings, we should evaluate it with the same criticism as we judge upon paternalism. Despite the potential of nudging for nursing, there is a risk to put the nurse again in the position of the paternalistic outsider who knows how people should behave. But maybe the awareness of the oughtonomous decisions we all make in our lives, can help us to understand why people act mindless in some situations or why we choose what we choose. Knowing this is one thing, giving people the authority of an expert to know what is better off for others, another. Despite the potential of the last, the former concept does not legitimate paternalistic interferences in patient's lifestyle.

\section{Key words}

Nudging, Paternalism, Autonomy, Heteronomy, Health choices, Obesity

\section{I ntroduction}

So many problems we are facing in today's nursing are situated at the intersection of autonomy and heteronomy, i.e. why well informed and autonomous people make unhealthy lifestyle choices although they really don't want to. If people do not choose what they want, is this simply caused by their lack of character or capability, or also by the fact that absolute autonomy is impossible? Obesity for instance: it is of course the individual who makes his or her own choices, but are the reasons why people choose what they choose solely based on autonomous motives ${ }^{[1]}$ ?

In our paper we will not only argue that heteronomy is inevitable, but also that a certain understanding of heteronomy can be differed from paternalism. We will describe the non-paternalistic heteronomy as 'oughtonomy', a neologism which obtains to express the intertwining of autonomy and 'ought', between independence and dependence ${ }^{[2]}$. Next to that, we will reflect upon how conditions within health care can improve our 'choice architecture', what Thaler \& Sunstein have 
called 'nudging': how to change individual health choices without being paternalistic ${ }^{[3]}$ ? We will consider out of the topical example of obesity how nursing from the perspective of nudging and oughtonomy, results in a practice which does not start from the question 'who is the one to blame', but rather 'how to be supportive for patients'? Our aim is to find out if a conceptual analysis of these two innovative concepts, can provide nurses from tools in helping people to get rid of their unhealthy lifestyle without punishing or blaming them.

\section{Autonomy whatever it takes?}

Autonomy is a major principle within nursing practice as it is for health care in general. In one way or another many patients have a desire to be involved in medical decisions ${ }^{[4]}$. Despite the often heteronymous circumstances people are put in when they enter a hospital, today's healthcare is focused on the maximization of the patient's autonomy, be it at the macro or the micro level ${ }^{[5]}$.

Although patient autonomy is essential for good caring practices in nursing, many people, also academics, have realized that the agency of autonomy never stands on its own. The myth of the independent autonomous individual taking rational decisions about his health and lifestyle is indeed a myth. All of us are related to an outer world, to family and networks of friends, etc. Consequently, more and more patient autonomy is understood as a thick concept or as 'relational autonomy' leaving the idea of fully independent beings behind ${ }^{[6,7]}$.

Related to this discussion, for a few years already, it is also popular to associate autonomy with the idea of 'empowerment', the enhancement of people's capacities to live their own lives in an autonomous way. People are coached or stimulated to take care personally of the chances they are offered, to make their autonomous choices and to live a life(style) which expresses consequently these choices ${ }^{[8-16]}$.

All of these efforts share the goal of decreasing heteronomy in people's lives by offering them the chances to be able to live their life according to the choices they personally have made; the more we can increase autonomy, the better off we will be and the better for our health ${ }^{[17,18]}$.

\section{Oughtonomy}

Although this tendency only seems to be positive in the light of care of the patient, our hypothesis is that it also mystifies a part of the health problems we are dealing with in today's society. As a great deal of the debate on autonomy in health care starts from the opposition of autonomy versus heteronomy or paternalism, it is also a way of misarticulating health problems. Numerous of these problems are not the result of too much paternalism and not enough autonomy, but of a multilayered interaction of autonomy and heteronomy. In many cases reality is very complex in the way autonomous and well-informed individuals are influenced by heteronymous aspects. If we limit the debate on autonomy to the question how to decrease heteronomy in healthcare, we (rightly) presume adult and informed people to make autonomous choices but we neglect the soil out of which people choose what they choose. This soil is what we have called 'oughthonomy' to pinpoint the interference of autonomy and heteronomy (the 'ought') present in numerous of today's medical problems ${ }^{[2]}$.

To mention only one example: if today so many people opt for esthetic surgery, can we at once conclude all of them have decided this autonomously? Even if they all have chosen this deliberately, there is still an undeniable dominant cultural tendency today you ought to construct your own body, instead of accepting it as your destiny. This 'ought' does not oblige us to do this or that in a coercive way - we are all convinced we decide autonomously and independently - but only its oughtonomous influence upon us can explain why so many people long for the same goals at the same time ${ }^{[12]}$. If today more and more healthy women visit health care to ask for the clinical procedure of labiaplasty for cosmetic reasons - the procedure alters the appearance of the labia - because they are convinced of the need of it ${ }^{[19]}$, it is likely that right at the 
very heart of their autonomous decision (from inside) for labiaplasty, an ought (from outside) is interfering their wish for more beautiful labia, a wish that hardly existed half a century ago.

This ought does not expunge the authenticity of the individual decision being made but questions the opposition between our inner selves and influences coming from 'outside' in making 'authentic' decisions as such. An analysis ${ }^{[1]}$ has been made of the neologism 'oughtonomy' to unravel this complex intersection between autonomy and heteronomy. When it comes down to human existence, autonomy and heteronomy are intertwined, more than they are merely opposites. Heteronomy, as is argued, is not the dark side of autonomy, and thus something that we should try to eliminate whatever it takes, but rather what 'constitutes' autonomy. Despite the overwhelming consensus about the advantages of autonomy, there are many good reasons to question the widely accepted opposition of autonomy and freedom versus heteronomy and paternalism.

Consequently, we want to reflect upon the 'disruptive' presence of heteronomy within the principle of autonomy. We prefer to elaborate the neologism oughtonomy in the context of nursing and obesity. Oughtonomy is relevant to the question how to prevent people from making unhealthy lifestyle choices: how to question the unhealthy choices people make, without being paternalistic? This question is prominently present in today' health care, from the debates on smoking cessation and alcoholism to diabetes and many other lifestyle diseases ${ }^{[16,20-22]}$.

Also nursing literature regularly starts from the opposition of autonomy and heteronomy because autonomy is conceived as positive while heteronomy is associated with 'old fashioned paternalism, ${ }^{[23-25]}$. The contemporary discourse in nursing, as it is for health care in general, is often about autonomy as an instigator of a healthy lifestyle and how to get rid of heteronomy ${ }^{[26-28]}$.

\section{Obesity}

Although the analysis of this problem can be applied to several contexts, in this text, we focus on one of the most topical examples of the questions mentioned above, namely obesity. If we for instance, for the sake of the argument, suppose obesity is solely a problem of individual autonomy, what would be the case? Then we would conceive of eating too much unhealthy food and having no physical activity as the result of deliberate and rational choices of an independent individual and consequently consider obesity as the result of this. Of course many options are available, but in this case often health care policy starts from the idea that the patient is to blame (the repressive version) or has to look for paternalistic help in restoring his life into a more healthy direction ${ }^{[29]}$.

On the other hand, we could opt for one or another version of the thesis by saying that the 'system' is responsible for everything, be it that the 'system' is called 'capitalism', 'genetics', 'family', 'education' or 'society'. Instead of being autonomous, people then are conceived as determined by inheritance or social circumstances which destine them to live their life as obese. In this case, heteronomy instead of autonomy is what matters.

The way obesity arises as one of the major health problems of our era needs another perspective and should take us away from the opposition between deliberate choices or determinants. One of the most intriguing questions in the context of obesity is why it has become a major problem in our era. Why are so many people acting in the same way at the same time and place? Is this really because all of a sudden, one by one, half of the western population quite independently chose to eat and drink too much and/or to no longer have any physical activity? Or is it because genetic determination all of a sudden arises after centuries of slumbering in our bodies?

The obviously rhetorical nature of these questions indicates that the answer 'no' can be taken as a given, and yet the point is nevertheless of crucial importance for current healthcare debates. In the context of mental illnesses, Ian Hacking described this phenomenon as 'transient illnesses': certain illnesses are typical for certain era's ${ }^{[30]}$. By this, he did not state 
that an era determines its illnesses and therefore illnesses can be reduced to it; all the more, he analyzes why certain illnesses are more present in certain era's than in others.

Also obesity can be described as a transient illness: it is a basic characteristic of our era, far more than it was before. Obesity is especially a problem of contemporary society. Everywhere in city streets, you can drink coke or eat burgers and all of us are on a daily basis faced with a battery of 'oughts', influences which can hardly be overestimated. Listen to the radio, watch television or walk on the streets: we all are bombarded with advertisements appealing us to enjoy our life via the consumption of food and beverages ${ }^{[31]}$.

Again, it is not a matter of using these 'oughts' as an alibi to explain why we in fact are the powerless products of overwhelming commercials. On the contrary, oughtonomy only explains why people, at the very moment they make up their own autonomous decisions, decide for things which are obviously analogous to the main characteristics of society, i.e. enjoyment of your personal life, put your desires first, etc. Despite the fact we are often very aware of the possible consequences of our decisions for our health, a lot of us keep on making unhealthy choices - it is for instance hard to say we are not informed about the dangers of smoking and yet many people continue smoking ${ }^{[32]}$.

\section{Nudging}

Let us summarize. The kernel of oughtonomy is many decisions taken from 'inside' are intertwined with oughts from 'outside', which makes of autonomy always also oughtonomy. What 'is me' is never simply me as pure autonomy but is also determined by other things (desires, social obligations, etc). With oughtonomy, we want to point at a growing area of medical problems also nursing has to deal with: unhealthy lifestyle choices made by independent people but which obviously witness of a heteronomy at work in their autonomous decisions.

Given this, we want to explore new paths and ways how health care in general and nursing in particular can take the challenge to tackle these problems. Although oughtonomy pinpoints at heteronomy, it is far from a starting point for one or another paternalistic plead. To start from the idea that an 'ought' always already intrudes my choices and decisions, does not offer us any argument for a renewal of paternalistic measures. The only conclusion to be made from oughtonomy is that inside of the autonomous individual, at the very moment it chooses, an 'ought' or an outside contaminates decisions taken. Oughtonomy therefore can make us aware of this intertwining of autonomy and heteronomy.

But given this oughtonomy at work in the context of obesity, how to cope with it? To detect a problem is one thing, to develop an appropriate remedy another. In other words: if we reflect upon obesity, how to find a professional attitude to help people not to choose the unhealthy way without being paternalistic?

In this context, it seems obvious to refer to the idea of empowerment: people should be made more capable of making the right choices ${ }^{[33-35]}$. As such, patient empowerment can be very helpful, but we should not make the mistake to pretend as if the only problem left in medicine is how to 'empower' individual patients so they would be able to make the right and autonomous choices. As the idea of patient empowerment runs the risk of reducing health problems to the responsibility of the autonomous individual, we want to take into care a broader perspective. People can be empowered to make the choices they prefer, but we should also reflect upon the conditions how society can improve our choice architecture and to make desirable - read: healthier - behavior more likely without imposing regulations to people.

In fact, this process is what Thaler \& Sunstein have called 'nudging' ${ }^{[3]}$. In their book Nudge they launched the idea of 'nudging' as the creation of a specific kind of incentives on how to stimulate healthier behavior without being paternalistic. A nudge is defined as "any aspect of the choice architecture that alters people's behavior in a predictable way

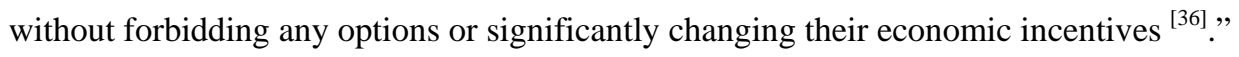


First of all nudging can be unintentional: when i.e. people join dinner together, they eat more than when they are alone. ${ }^{[0]}$ Or for instance if your best friends get fat, your risk of gaining weight goes up ${ }^{[3]}$. In many of this cases it is unlikely that someone intentionally nudges the others to eat more, and yet it happens although it is hard or even impossible to hold someone personally responsible for it. Group average, gender differences and many other factors do exert significant influence upon our consumption behavior. Also the effect of arousal can be very significant. Many people start their dinner with refusing some cashews - 'I'm on a diet' - but end up with a giant desert, as the others ordered also one.

Nudging differs from liberalism and from paternalism. It differs from liberalism since it includes the idea that although people make their own decisions, they are never simply autonomous and it is therefore public health's responsibility to help them in making healthier (lifestyle) choices. In fact, nudging starts from the idea that a lot of societal and individual good comes from public health. Nevertheless, it differs from 'old fashioned paternalism' because as such it does not limit our alternatives or prevents us from making unhealthy choices by legislation. Nudging is aware of the 'influence from outside', even if we make autonomous decisions, and it seeks for opportunities for all of us to get stimulated in a more healthy way ${ }^{[37,38]}$.

\section{Nursing and obesity}

Of course nudging can also be part of a strategy for instance advertisers often fall back upon to influence our eating behavior or lifestyle choices in general. Numerous advertisements are tempting us by referring to a sort of sense of belonging or community when consuming their products, or obtain to convince us of what other people use to do; ads function as a model of what we ought to do.

As nudging can be a strategy of advertisers, it can also be used for governments or public health institutions to stimulate people in order to make healthy lifestyle choices. Although a nudge excludes regulation or legislation or measures taken from above - this is what we still call paternalism - this does not imply that no interventions whatsoever are forbidden, Thaler \& Sunstein argue. For instance putting vegetables instead of candy at eye level is a nudge: it influences our choices while it does not forbid us to buy candy - of course supermarkets commonly use the opposite strategy: they put the things we don't need at an eye level, so we buy them also.

Consequently, we can wonder if nudging can be integrated in a nursing practice as a strategy to prevent people from making unhealthy lifestyle choices, without falling back upon paternalistic measures. Since influence does not start with the idea that governments make efforts to change our lifestyle behavior, heteronomy is always already at work without calling this paternalism; i.e. did any of us complain about the paternalistic influence of ads upon our eating (or dieting) behavior?

When it comes down to nudge people with overweight problems in a nursing context, we can be creative. Imagine a scenery quite familiar to many family nurses: they visit a family of which the man is on a diet. Every time they pass by the table is full of candy's and other fatteners. A paternalistic measure would include a preach pointing at bad the man's behavior and some measures to forbid the man ever eating candy's again. A nudge on the contrary would imply to think in a creative way which mechanisms could help this man, i.e. by offering him a deal such as: every time he gains weight, he pays the nurse a check of an agreed sum of money she can spend to buy him fruits and vegetables the next time she comes around.

If nudging means nursing can help and support patients to lead healthier lives, obesity is indeed a topical example. Not only in hospitals or in family nursing but also in community health care centers where nursing is included, prevention has become very important for nurses. One of the most stubborn obstacles they are confronted with time and again is the conflict between the health imperatives from the nursing point of view, and the choices people make because they want them to make, although they often know very well they are bad for their health ${ }^{[39]}$. 
Most nurses, in their practice, already developed techniques of communication to 'convince' people from making better choices, but it is always a thin line between helping people and blaming them from what they have not done ${ }^{[40]}$. Nudge theory can be an instrument of help to safeguard nursing from becoming paternalistic (negatively), and it can add legitimacy to many of the influential techniques that they already use (positively).

With obese people, nurses often feel powerless in attempting patients to move them in directions that will make their lives better, without playing their nanny or limit their options from outside ${ }^{[41]}$. Nudging can be of help here. Think for instance about the use of 'fully sugar loaded' beverages. A paternalistic measure towards obese patients would be to expel all beverages from their environment to 'protect them' from being able to make this unhealthy choice. A liberal point of view would conclude that some people make healthy choices and others do not, but that it is up to them to decide that.

The perspective of nudging would be something in between: for instance to make free water available next to every beverage selling point, you invite people to think about an alternative and you offer them to save money as well, while you don't need any legislation to provide this. Nursing can be part of this restructuring of a healthy environment. Not only by being creative in this and to partake in facilitating more healthy choices, but also by pointing people at existing alternatives. If obese patients are struggling with the choices they made, nursing practice can be of help with seeking in advance for alternatives at moments it is probably hard to resist the temptation of unhealthy consumerism.

\section{You ought to nudge?}

Above we only illustrated the opportunities in one particular case but of course we can think about rather global kinds of 'government-imposed self-control', from discourage consumption without forbidding it, over offering people with a gambling problem to put themselves on a list of people who are banned from casino's, to help people in saving money by putting voluntarily a weekly sum on an account and install high transition costs so they are discouraged to take the money out again on a regular basis (almost the opposite of buying on credit). No need to mention that it is crucial never to impose measures upon people, but to facilitate them to restrain themselves with you or other people as an external backup ${ }^{[42]}$.

Although nudging might be of help in many nursing settings, we should evaluate it with the same criticism as we judge upon paternalism. Firstly, if the criterion for nudging, as Thaler \& Sunstein claim, is the well-being of the person being nudged as he judges himself, isn't it inevitable that the same 'ought', as discussed above, will contaminate this judgment? And secondly, as Robert Sugden has also stated in his review of Nudge, "how do Thaler\& Sunstein justify the particular interventions they propose ${ }^{[36]}$ ?” Should we therefore not be suspicious of the experts called 'choice architects' who obviously know very well what is in our best interest?

Being an outsider, any expert can of course evaluate people's behavior and look for the unhealthy aspects of it and imagine how they would be better off by making other more healthy choices. What really matters is, do we want this? As the expert is obviously someone who knows at what point what is good for our not to say my health ${ }^{[41]}$ ? Judging from outside on what is the best in our interest, is exactly what the paternalist does. Thaler \& Sunstein claim that the choice architect differs from the paternalist because the individual still has a free choice, but at least he puts some serious restraints on this freedom. Unless the nudger withdraws himself, can he be otherwise than paternalistic by convincing the nudgee he ought to be nudged because he, being an expert, knows more than the nudgee which choices are good for his health and which are not? Is this not a very smooth way of making paternalism acceptable again?

Not only we can ask for the position of the nudger, but also to that of the nudgee. If the difference between paternalism and nudging implies that the nudger starts from the nudgee judging himself, how then to be sure in advance that people while allow others to judge themselves as making bad (unhealthy) choices? In many nursing situations, this is exactly the problem. If i.e. have to go on a diet they often simply refuse advice from outside because they just want to live on as they 
used to do. In short, in some cases people might want to be judged, but in many cases they might not. What about these? Will the expert stick onto his outside position or will he develop more rigid constraints to our 'free choice'?

But even if this were not the case and an individual judges himself, is there any argument to believe that this judgment will not be influenced by the same heteronomy at work in the numerous situations we need nudging to change our health behavior because we acted as conformist in these situations? And if not, why would people then act mindless all the time on the one hand and be rational in their self-evaluation on the other hand?

Thaler \& Sunstein acknowledge heteronomy being inevitably at work in your thinking and acting, but it seems that they still hope for a point of pure rationality in which we look at ourselves in the most independent and autonomous way, liberated from any kind of influence from outside. And if apparently the nudgee is often unable to do this, why should the expert be rational in the application of his expertise in a choice architecture? Will an expert not also be influenced by the 'oughts' from outside?

\section{Concluding remarks}

Despite the potential of nudging for nursing, there is a risk to put the nurse - presupposing he or she is the health expert back again in the position of the paternalistic outsider who knows how people should behave. Nurses face many dilemma's in which they hope people will act otherwise because indeed their health would be better off or it would make them more able to find a new job or whatsoever; but in the end, do nurses not have to respect the people's own preferences to live the life they want to? Of course, this rhetorical question is as such no universal argument to legitimate all kinds of behavior. But maybe the awareness of the oughtonomous decisions we all make in our lives, can help us to understand why act mindless in some situations or why we choose what we choose. Knowing this is one thing, giving people the authority of an expert to know and to decide what is better off for others, another. Despite the potential of nudging, oughtonomy does never legitimate paternalistic interferences in patient's lifestyle while nudging implicitly does ${ }^{[43]}$.

\section{References}

[1] Devisch, I., Deveugele, M. Lifestyle: Bioethics at a Critical Juncture. Cambridge Quarterly of Healthcare Ethics. 2010; 19(4): 550-558. PMid:20719038 http://dx.doi.org/10.1017/S0963180110000502

[2] Devisch, I. Oughtonomy in healthcare. A deconstructive reading of Kantian autonomy. Medicine, Health Care and Philosophy. 2010; 1-10. PMid:19830592

[3] Thaler, R. H., \& Sunstein, C. R. Nudge. Improving decisions about health, wealth and happiness. London: Penguin Books. 2008.

[4] Cullati, S., Courvoisier, D. S., Charvet-Berard, A. I., Perneger, T. V. Desire for autonomy in health care decisions: a general population survey. Patient Educ Couns. 2011; 83(1): 134-138. PMid:20605695 http://dx.doi.org/10.1016/j.pec.2010.04.025

[5] Bærøe, K. Priority setting in health care: on the relation between reasonable choices on the micro-level and the macro-level. Theoretical Medicine and Bioethics. 2008; 29(2): 87-102. PMid:18528781 http://dx.doi.org/10.1007/s11017-008-9063-3

[6] Ho, A. The individualist model of autonomy and the challenge of disability. Journal of Bioethical Inquiry. 2008; 5(2-3): $193-207$. http://dx.doi.org/10.1007/s11673-007-9075-0

[7] Moser, A., Houtepen, R., Spreeuwenberg, C., Widdershoven, G. Realizing autonomy in responsive relationships. Medicine Health Care and Philosophy. 2010; 13(3): 215-223. PMid:20339930 http://dx.doi.org/10.1007/s11019-010-9241-8

[8] Beaudoin, C. E., Thorson, E., Hong, T. Promoting youth health by social empowerment: a media campaign targeting social capital. Health Commun. 2006; 19(2): 175-182. PMid:16548708 http://dx.doi.org/10.1207/s15327027hc1902_9

[9] Chard, R. Trends in public financing of health care for the elderly in the United States: social constructions and political empowerment. Appl Health Econ Health Policy. 2002; 1(3): 117-120. PMid:14619260

[10] Gagnon, M., Hibert, R., Dube, M., Dubois, M. F. Development and validation of an instrument measuring individual empowerment in relation to personal health care: the Health Care Empowerment Questionnaire (HCEQ). Am J Health Promot. 2006; 20(6): 429-435. PMid:16871823 http://dx.doi.org/10.4278/0890-1171-20.6.429

[11] McWaters, N., Hurwood, C., Morton, D. Step by step on a piece of string: an illustration of community work as a social health strategy. Community Health Stud. 1989; 13(1): 23-33. http://dx.doi.org/10.1111/j.1753-6405.1989.tb00173.x

Published by Sciedu Press 
[12] Mogford, E., Gould, L., Devoght, A. Teaching critical health literacy as a means to action on the social determinants of health. Health Promot Int. 2010.

[13] Parsons, C. The health promoting school and social justice in a global environment. Asia Pac J Public Health. $2004 ; 16$ Suppl: S42-47. PMid:15828510

[14] Raeburn, J., Beaglehole, R. Health promotion: can it redress the health effects of social disadvantage? Community Health Stud. 1989; 13(3): 289-293. http://dx.doi.org/10.1111/j.1753-6405.1989.tb00208.x

[15] Ridde, V. Reducing social inequalities in health: public health, community health or health promotion? Promot Educ. 2007; 14(2): 63-67, 111-114. http://dx.doi.org/10.1177/10253823070140021401

[16] Taylor, G., Hawley, H. Health promotion and the freedom of the individual. Health Care Anal. 2006; 14(1): 15-24. PMid:17137016 http://dx.doi.org/10.1007/s10728-006-0012-x

[17] Azetsop, J., Rennie, S. Principlism, medical individualism, and health promotion in resource-poor countries: can autonomy-based bioethics promote social justice and population health? Philos Ethics Humanit Med. 2010; 5: 1. PMid:20082703 http://dx.doi.org/10.1186/1747-5341-5-1

[18] Swindell, J. S., McGuire, A. L., \& Halpern, S. D. Shaping Patients’ Decisions. Chest. 2011; 139(2): 424-429. PMid:21285056 http://dx.doi.org/10.1378/chest.10-0605

[19] Liao, L. M., Michala, L., Creighton, S. M. Labial surgery for well women: a review of the literature. BJOG: An International Journal of Obstetrics \& Gynaecology. 2010; 117(1): 20-25.

[20] Buchanan, D. R. Autonomy, Paternalism, and Justice: Ethical Priorities in Public Health. American Journal of Public Health. 2008; 98(1): 15-21. PMid:18048780 http://dx.doi.org/10.2105/AJPH.2007.110361

[21] Erdem, A. The Principle of Respect For Autonomy Of The Patient In Medical Ethics. Erciyes Medical Journal. $2003 ; 25(2), 92-97$.

[22] Nys, T. R. V. Paternalism in Public Health Care. Public Health Ethics. 2008; 1(1): 64-72. http://dx.doi.org/10.1093/phe/phn002

[23] Breier-Mackie, S. Patient autonomy and medical paternity: Can nurses help doctors to listen to patients? Nursing Ethics. 2001; 8(6): 510-521. PMid:16004106

[24] Camden, S. G. Ethical Realities of Bariatric Nursing: A Case Study Approach to Real-World Dilemmas Part 2: Paternalism-Recognizing the Tension between Beneficence and Autonomy. Bariatric Nursing and Surgical Patient Care. 2009; 4(3): 185-190. http://dx.doi.org/10.1089/bar.2009.9966

[25] Zomorodi, M., Foley, B. J. The nature of advocacy vs. paternalism in nursing: clarifying the 'thin line'. Journal of Advanced Nursing. 2009; 65(8): 1746-1752. PMid:19493141 http://dx.doi.org/10.1111/j.1365-2648.2009.05023.x

[26] McCormack, B. Autonomy and the relationship between nurses and older people. Ageing and Society. 2001; 21: 417-446. http://dx.doi.org/10.1017/S0144686X01008303

[27] Skar, R. The meaning of autonomy in nursing practice. Journal of Clinical Nursing. 2010; 19(15-16): 2226-2234. PMid:19538554

[28] Young, A. Review: the legal duty of care for nurses and other health professionals. Journal of Clinical Nursing. 2009; 18(22): 3071-3078. PMid:19825113 http://dx.doi.org/10.1111/j.1365-2702.2009.02855.x

[29] Saguy, A. C., Riley, K. W. Weighing Both Sides: Morality, Mortality, and Framing Contests over Obesity. Journal of Health Politics, Policy \& Law. 2005; 30(5): 869-921. PMid:16477791 http://dx.doi.org/10.1215/03616878-30-5-869

[30] Hacking, I. Mad Travellers: Reflections on the Reality of Transient Mental Illnesses. London: Free Association Books. 1998.

[31] Minkler, M. Personal Responsibility for Health? A Review of the Arguments and the Evidence at Century's End. Health Education \& Behavior. 1999; 26(1): 121-141. http://dx.doi.org/10.1177/109019819902600110

[32] Devisch, I., Dierckx, K. On idiocy or the plea for an Aristotelian health policy. Public Health. 2009; 123(7): 514-516. PMid:19524273 http://dx.doi.org/10.1016/j.puhe.2009.04.009

[33] Kligler, B. Patient empowerment: taking integrative medicine to the next level. J Altern Complement Med. 2007; 13(2): 189-190. PMid:17388759

[34] Loukanova, S. N., Bridges, J. F. P. Empowerment in medicine: An analysis of publication trends 1980-2005. Central European Journal of Medicine. 2008; 3(1): 105-110. http://dx.doi.org/10.2478/s11536-007-0066-7

[35] Minkler, M. Challenges for health promotion in the 1990s: social inequities, empowerment, negative consequences, and the common good. Am J Health Promot. 1994; 8(6): 403-413. PMid:10172080 http://dx.doi.org/10.4278/0890-1171-8.6.403

[36] Sugden, R. On Nudging: A Review of Nudge: Improving Decisions About Health, Wealth and Happiness by Richard H. Thaler and Cass R. Sunstein. International Journal of the Economics of Business. 2009; 16(3): 365-373. http://dx.doi.org/10.1080/13571510903227064

[37] John, P., Smith, G., Stoker, G. Nudge Nudge, Think Think: Two Strategies for Changing Civic Behaviour. Political Quarterly. 2009; 80(3): 361-370. http://dx.doi.org/10.1111/j.1467-923X.2009.02001.x

[38] Karim, S., King, D., Darzi, A. Nudging. British Journal of General Practice. 2011; 61(584): 223-223. PMid:21375914 http://dx.doi.org/10.3399/bjgp11X561311 
[39] Blue, L. Prevention: How much can doctors and nurses really change your lifestyle choices? Time [Internet]. 2009 , August 21. Available from:

http://healthland.time.com/2009/08/21/prevention-how-much-can-doctors-and-nurses-really-change-your-lifestyle-choices/\#ixzz 1gzQCW3jU

[40] McLaughlin, N. Stop blaming the patient. Penalizing workers for personal health decisions is off-the-mark. Mod Healthc. 2008; 38(7): 25.

[41] Cody, W. K. Paternalism in Nursing and Healthcare: Central Issues and their Relation to Theory. Nursing Science Quarterly. 2003; 16(4): 288-296. PMid:14596114 http://dx.doi.org/10.1177/0894318403257170

[42] Marteau, T. M., Ogilvie, D., Roland, M., Suhrcke, M., Kelly, M. P. Judging nudging: can nudging improve population health? BMJ. 2011; 342: d228. PMid:21266441 http://dx.doi.org/10.1136/bmj.d228

[43] Vallgårda, S. Nudge-A new and better way to improve health? Health Policy (0). 2011. 